\title{
Preliminary evidence for seasonality of Covid-19 due to
}

\section{ultraviolet radiation [version 1; peer review: 1 approved with}

\section{reservations, 1 not approved]}

\section{Christos Karapiperis ${ }^{1}$, Panos Kouklis 2,3 , Stelios Papastratos ${ }^{4}$, Anastasia Chasapi ${ }^{4}$ Antoine Danchin 5,6 , Christos A. Ouzounis (iD) 4}

\footnotetext{
${ }^{1}$ School of Informatics, Aristotle University of Thessaloniki, Thessalonica, Thessalonica, 54124, Greece

2Laboratory of Biology, Medical School, University of Ioannina, Ioannina, Ioannina, 45110, Greece

${ }^{3}$ Department of Biomedical Research, Institute of Molecular Biology \& Biotechnology FORTH, Ioannina, Ioannina, 45115, Greece

${ }^{4}$ Chemical Process \& Energy Resources Institute, Centre for Research and Technology Hellas, Thermi, Thessalonica, 57001, Greece

${ }^{5}$ Kodikos Labs, Kodikos Labs, Lyon, Lyon, 69007, France
}

${ }^{6}$ Institut Cochin, Institut Cochin, Paris, Paris, 75013, France

\section{V1 First published: 30 Jun 2020, 9:658 \\ https://doi.org/10.12688/f1000research.24774.1 \\ Latest published: 30 Jun 2020, 9:658 \\ https://doi.org/10.12688/f1000research.24774.1}

\section{Abstract}

The Covid-19 pandemic has spread across the world during early 2020, with unforeseen consequences. Beyond social measures and biomedical research, it is important to assess the seasonality of the epidemic to inform strategies, with limited available data in the short period of time between the March equinox and the June solstice. While the effect of multiple factors is being investigated, little attention has been paid to ultraviolet (UV) radiation, a key parameter of seasonal forcing. We review the effects of UV radiation, proposing it as a potential element of seasonality, and provide evidence from the current literature and scant, yet revealing, observations. Explicit consideration should be given to UV radiation for the seasonality of Covid-19 at high latitudes and altitudes, based on the SARS and MERS epidemics and coronavirus diseases, and not just the 'warmer days' of summer.

\section{Keywords}

Covid-19, Seasonality, Ultraviolet radiation

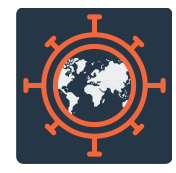

This article is included in the Emerging Diseases and Outbreaks gateway.

\section{Open Peer Review}

\begin{tabular}{lcc} 
Approval Status & ? \\
& 1 & 2 \\
\hline version 1 & $?$ & $\times$ \\
30 Jun 2020 & view & view
\end{tabular}

1. Gustavo Zubieta-Calleja (iD), High Altitude Pulmonary and Pathology Institute IPPA, La Paz, Bolivia

2. Matthew Baylis ID, University of Liverpool, Liverpool, UK

Any reports and responses or comments on the article can be found at the end of the article. 
HEAL

1000

This article is included in the HEAL1000

gateway.

This article is included in the Coronavirus

collection.

Corresponding author: Christos A. Ouzounis (ouzounis@certh.gr)

Author roles: Karapiperis C: Data Curation, Investigation, Software, Validation, Writing - Review \& Editing; Kouklis P:

Conceptualization, Investigation, Validation, Writing - Review \& Editing; Papastratos S: Conceptualization, Investigation, Methodology, Validation, Writing - Review \& Editing; Chasapi A: Investigation, Validation, Writing - Review \& Editing; Danchin A: Conceptualization, Investigation, Methodology, Validation, Writing - Review \& Editing; Ouzounis CA: Conceptualization, Data Curation, Project Administration, Supervision, Visualization, Writing - Original Draft Preparation, Writing - Review \& Editing

Competing interests: No competing interests were disclosed.

Grant information: The author(s) declared that no grants were involved in supporting this work.

Copyright: (c) 2020 Karapiperis C et al. This is an open access article distributed under the terms of the Creative Commons Attribution License, which permits unrestricted use, distribution, and reproduction in any medium, provided the original work is properly cited.

How to cite this article: Karapiperis C, Kouklis P, Papastratos S et al. Preliminary evidence for seasonality of Covid-19 due to ultraviolet radiation [version 1; peer review: 1 approved with reservations, 1 not approved] F1000Research 2020, 9:658

https://doi.org/10.12688/f1000research.24774.1

First published: 30 Jun 2020, 9:658 https://doi.org/10.12688/f1000research.24774.1 
Much attention has been paid by news reports, publications, press releases, preprints and white papers concerning containment measures for the Covid-19 pandemic, caused by the highly infectious and contagious virus SARS-CoV-2 in the humanto-human transmission chain (Anderson et al., 2020). From the onset of the epidemic, the naming of the new disease was not reminiscent of the previous, related disease SARS (Holmes, 2003), perhaps generating a certain degree of incertitude. The term Covid-19 has obfuscated its similarity and kinship to SARS for the public, with an initial tepid response in the Western world, as the disease started spreading globally. If Covid-19 had not been initially contrasted to influenza, responses might have been stronger and more efficient (Vetter et al., 2020). This is all history. Now, there is an acute need for swift, simple measures that can limit global contagion (Hunter, 2020), and ways to understand the epidemic response to climate factors.

There have been multiple reports and, admittedly, a hope that Covid-19 might exhibit a seasonal pattern, that will slow down the spread of the epidemic (Bukhari \& Jameel, 2020). In fact, the initial confusion with flu-like symptoms might have contributed to this propitious hypothesis, obscuring the dangers for the epidemic in areas such as sub-Saharan Africa (Araújo \& Naimi, 2020). A host of studies have examined seasonal fluctuations and regional climate parameters, including temperature (Auler et al., 2020; Shi et al., 2020), humidity (Luo et al., 2020), a combination of both (Mecenas et al., 2020; Sahin, 2020; Sajadi et al., 2020; Wu et al., 2020), along with wind speed (as an indicator for long-range airborne spread) (Chen et al., 2020), precipitation levels (Oliveiros et al., 2020), some in conjunction to population density (Liu et al., 2020; Pedrosa, 2020). Yet, only minor correlations with temperature, even controlling for a lag of detected cases, (Ma et al., 2020; Shi et al., 2020) or precipitation (Sobral et al., 2020) have been observed. Press releases reporting these studies state that seasonality can be a significant factor with summer days approaching. However, at the time of initial writing and review in parallel with the appearance of these reports, Northern and Southern hemispheres were at the March ('Spring' for the North) Equinox or just after it, confounding real-time analysis and derivation of solid conclusions that connect the epidemic with seasonal fluctuations to a certain extent (BannisterTyrrell et al., 2020), with little or no evidence found for local temperature effects, e.g. Spain (Briz-Redón \& Serrano-Aroca, 2020) or Japan (Ujiie et al., 2020). Previous findings on the diminished presence of SARS-CoV on surfaces at higher temperatures, attenuating transmission, have been pointed out (Bannister-Tyrrell et al., 2020). Additional evidence for potential

seasonality of Covid-19 arises from four other endemic coronaviruses, despite a significant uncertainty in epidemiological parameters, with the risk of a false impression of containment over the summer period (Neher et al., 2020).

Sunlight, as the surrogate and key element of seasonality, emits at infrared (IR), visible and ultraviolet (UV) wavelengths. While IR is responsible for heat transmission with low-energy electromagnetic (EM) waves, UV is responsible for high-energy EM waves - even at low temperatures, e.g. at high altitude or high latitudes ${ }^{1}$. Therefore, any assessment for the seasonality of Covid-19 should consider UV emission (typically UV-A or -B for sunlight), also hinting at the targeted deployment of artificial UV-C rays (naturally absorbed by the atmosphere and the ozone layer $)^{2}$. In addition, it should be noted that extensive UV exposure can occur even in overcast skies, as this EM wavelength can penetrate water-droplet clouds that diminish UV radiation by as little as 15\% (Calbó et al., 2005). Finally, there is also a correlation between vitamin $\mathrm{D}$ and $\mathrm{UV}$, which implicates $\mathrm{UV}$ in human physiology (Asyary \& Veruswati, 2020; Engelsen, 2010; Juzeniene et al., 2010; Tamerius et al., 2011). Statements concerning the absence of UV effects on Covid-19 seasonality over a short period of time and in an area with multiple confounding factors cannot be conclusive, as previously shown (Yao et al., 2020). More comprehensive studies now appearing suggest otherwise, suggesting a role for UV (Carleton et al., 2020) (Box 1). Consequently, there should be more focus on the effects of UV radiation, as a parameter that might slow virus transmission in open spaces under natural light and solar UV exposure as summer days are longer, in the period examined so far (Chiyomaru \& Takemoto, 2020) ${ }^{3}$. Artificial sources of

Box 1. Timeline of UV-related Covid-19 seasonality literature - following publication of our initial hypothesis (https://osf. io/397yg/ (Karapiperis et al., 2020); 26-March-2020)

14-Apr: Chiyomaru \& Takemoto, 2020

16-Apr: Merow \& Urban, 2020

27-Apr: Asyary \& Veruswati, 2020

28-Apr: Carleton et al., 2020

07-May: Yao et al., 2020

${ }^{1}$ https://www.ncbi.nlm.nih.gov/books/NBK304366/

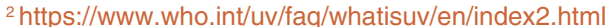

${ }^{3}$ Preprint (https://osf.io/397yg/) was the first report on UV as a factor for Covid-19 seasonality (Box 1). 
UV (-C) light for built environments that can be installed to eliminate the spread of infectious viral particles in public spaces can be deployed. Known examples include the use of UV to eradicate SARS-CoV-2 from banknotes, buses and hospitals. Indeed, studies on the related SARS-CoV report virion inactivation using $254 \mathrm{~nm} \mathrm{UV}$ light, heat or chemicals (Darnell et al., 2004).

It is known that UV light (i.e. UV-C) affects nucleic acids in a detrimental fashion for organisms, including viruses and bacteria, with ssRNA viruses being more sensitive than other viral types by 2 - to 3 -fold (Tseng \& Li, 2007). Germicidal UV is standard practice for cell culture and sterilization protocols ( $\mathrm{Li}$ et al., 2005; Rae et al., 2008). Studies on the H1N1 influenza virus report inactivation with low doses of $222 \mathrm{~nm}$ UV light, suggesting potential low dose-rate UV-C radiation solutions for reducing the spread of viral infections across indoor public spaces (Welch et al., 2018). Interestingly, a recent study on the effect of meteorological factors on influenza virus in Northern Europe has found some correlation between UV and spread of the epidemics during 2010-2018 (Ianevski et al., 2019), thus pinpointing one of the elements of seasonality, albeit for a different infectious disease. It is not known how resilient SARS-CoV-2 can be under strong, short-wave UV light, yet application of technologies, such as appropriate LED or UVarrays, no matter how expensive, could in principle be deployed in crowded spots, such as mass transport systems, with a certain urgency.

There is limited information for non-human hosts of coronaviruses in the wild. It is remarkable, however, that a survey of populations for eight species of seabirds in the Southwestern Indian Ocean - including Réunion and Madagascar - did not detect any coronavirus presence in 338 samples, of which only a handful (39) were collected during the winter (Lebarbenchon et al., 2013). This serendipitous observation might suggest that the summer sun keeps these populations in the wild healthy and protects them from viral infections, however mild. More research into that direction will definitely be worthwhile, as the analogy of this finding cannot be readily translated for public health: neither the role of UV radiation nor seasonality can be inferred from these remarkable observations (C. Lebarbenchon, personal communication, University of Réunion). How wildlife responds to coronavirus infections with regard to seasons and climate change is not entirely understood at present.

Regarding seasonality, our guide should be coronavirus epidemiology in general (Neher et al., 2020; Nickbakhsh et al., 2020), and the SARS/MERS outbreaks and their containment in particular - maybe more so than the flu. While models accept, simulate and interpret seasonality (Carleton \& Meng, 2020; Kissler et al., 2020; Li et al., 2020), they do not usually refer to UV radiation in an explicit manner (rate, i.e. strong sunshine, or duration, i.e. day length). In the case of SARS and MERS, these epidemics did not spread widely, due to containment and mitigation strategies, including limited quarantine, which is not comparable to the scale we are experiencing today globally (Nickbakhsh et al., 2020). For instance, seasonal fluctuation for MERS was primarily limited at latitudes as low as $20^{\circ}$ - in Saudi Arabia with high temperatures - although most infections occurred within hospitals (Zumla et al., 2015), and over a short period, at $40^{\circ}$ latitude, e.g. in South Korea (Kim et al., 2017). We need to know how SARS-CoV-2 responds to UV and what its viability is on surfaces (van Doremalen et al., 2020), under simulated sunlight, which is currently unknown. Any chance of seasonal variation will provide valuable time in the North and ring an alarm in the South, as modelling the variation of UV radiation and temperature suggests a decline during summertime (Merow \& Urban, 2020), with this study being the first following our initial hypothesis connecting UV radiation with Covid-19 growth rates (Karapiperis et al., 2020).

Seasonal fluctuation can be a factor that will limit Covid-19, and the reason may not be due to high temperatures - as the media, but also a number of epidemiological studies, keep on reporting - but sustained UV radiation (Merow \& Urban, 2020), as demonstrated in comparative studies (Lytle \& Sagripanti, 2005). One piece of evidence is that, until the March Equinox 2020, Covid-19 was imported into the Southern Hemisphere but did not achieve epidemic status rapidly until recently (Figure 1). It is challenging to compare spread in real time for seasonality (Martinez, 2018), with 90\% of the human population residing in the Northern Hemisphere. Using data from Peru, a country with the highest UV levels (Suarez Salas et al., 2017), there is a correlation between elevation and incidence, along population density (Figure 2), as latitude comparisons are not currently feasible. High-elevation countries such as Bhutan and Nepal exhibit low incidence rates for Covid-19, while exceptions due to travel patterns include countries as diverse as Andorra and China, all in the Northern hemisphere.

As summer is approaching in the North, with increased UV radiation due to increased day length, there is a chance for a decelerating pace of transmission in the open. 


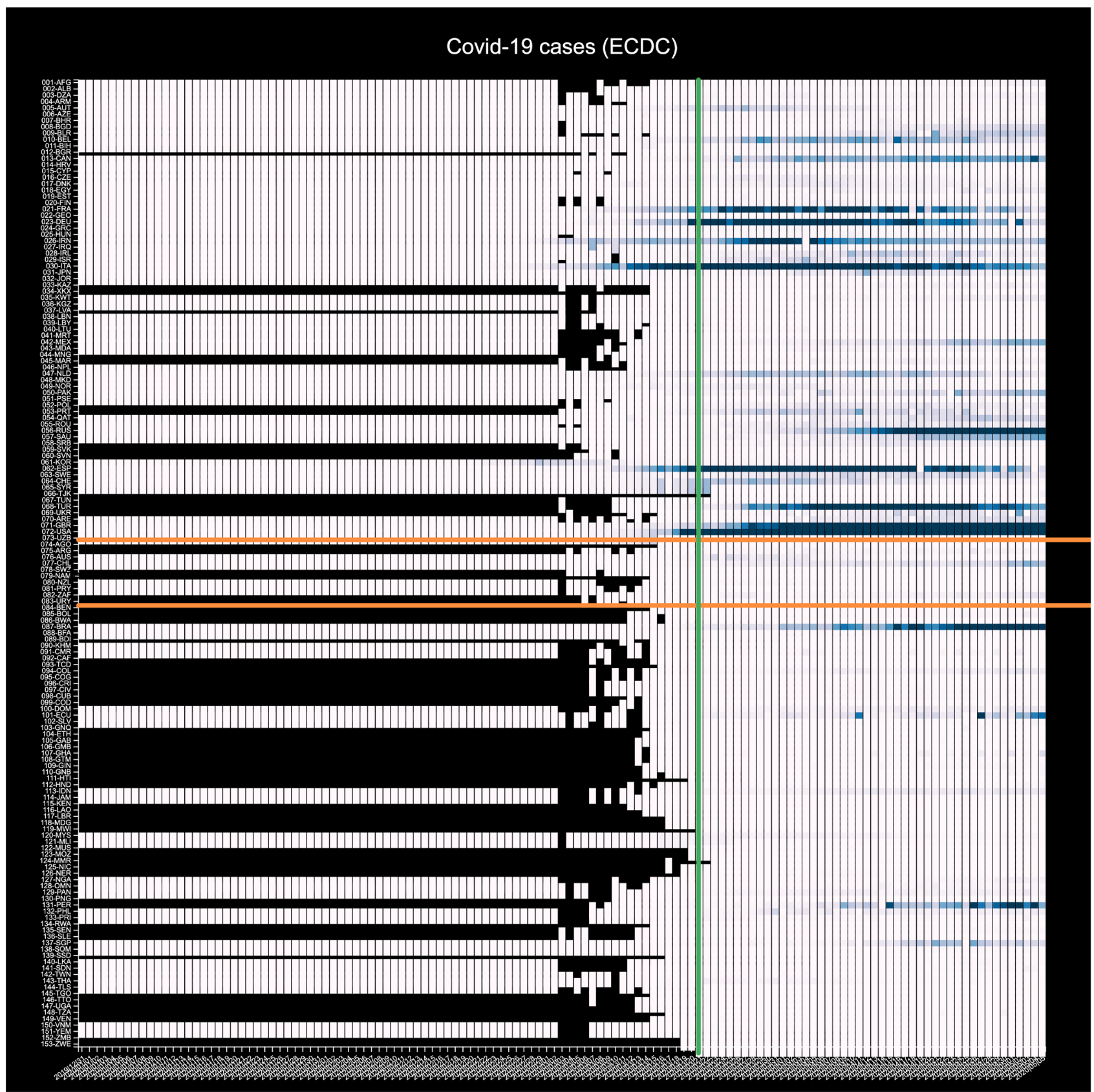

Figure 1. Pictorial representation of Covid-19 across three sets of countries, over time. Data were imported from ECDC and refer to the period 31-Dec-2019 to 5-May-2020, () ECDC (2005-2019). Cross-checks with other datasets were performed, e.g. from HealthMap (Xu \& Kraemer, 2020) (https://www.healthmap.org/covid-19/). Visualization was facilitated by Charticulator (https://charticulator.com/app/index html, (c) 2018 Microsoft Corporation). Dates are shown on the x-axis, per day (vertical green line signifies the March equinox). Countries are classified in three groups on the y-axis (separated by horizontal lines, in orange) and listed alphabetically to avoid clashes over latitudes - top: Northern (73), middle: Southern (10) for contrast to North, bottom (70): equatorial (between 23N and $23 \mathrm{~S}$ ), 153 in total. Daily counts normalized per 100K population (shown in cells), to display spread (light: low values, dark: high values). It can be seen that at most countries in the North, there is some attenuation, except Russia, Turkey, the UK and the USA at present (dark-blue, at the top block). While many other factors contribute to the spread, it remains to be seen whether the pandemic will switch across North and South, indicating a seasonality pattern, with UV as a salient element compared to the more variable parameter of average daily temperature - and despite the fact of a large number of recorded cases. This will crucially depend on mitigation measures, travel restrictions and various other public health strategies around the world. 

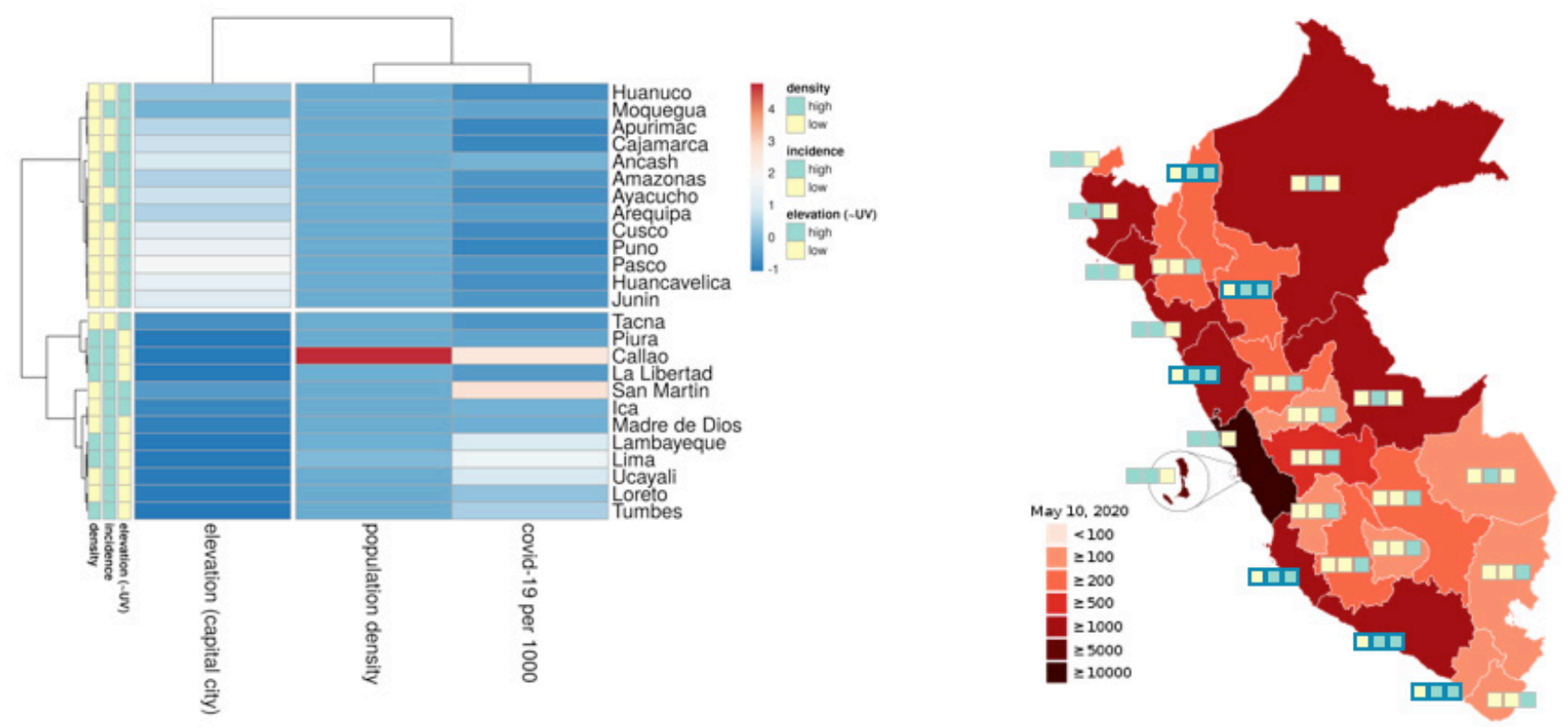

Figure 2. Covid-19 incidence in Peru compared to elevation as a proxy for UV radiation. A cursory view of the situation using elevation, as seasonality is currently difficult to track (see main text). We assess incidence in Peru, as the country with the highest UV radiation levels and high elevation contrasts (Suarez Salas et al., 2017). Reported Covid-19 cases in 25 departments (provinces) (from: https://covid19.minsa.gob. pe/sala_situacional.asp), 5-May-2020. Despite the fact that case reports have a resolution per province, there is a trend for high incidence in the low-lying East and coastal plains, while high altitudes with increased UV radiation levels (Suarez Salas et al., 2017) have lower counts. Left panel, generated by ClusVis (Metsalu \& Vilo, 2015): Heatmap of PCA-based clusters, using correlation as a metric and complete linkage clustering for elevation, Covid-19 incidence (per thousand population) and population density, the latter used to capture crowding effects. Unit variance scaling applied to columns, scale shown (top right). Annotations: green for high, yellow for low - thresholds: high density $>50 / \mathrm{km} 2$, high incidence $>568 \mathrm{pM}$ (world average 13-May-2020), high elevation $>200 \mathrm{~m}$. Annotations on the left block of the heatmap (also shown on the country map, right panel): 19/25 provinces consistent with high density/incidence and low elevation (6), and low density with low incidence/high elevation (10) or the reverse (3). There are just 6/25 provinces of low density and high incidence/elevation (inconsistent with UV-vs-incidence), four of which being coastal. Two clusters in rows and columns shown, delineating low-density/high-elevation provinces (bottom cluster, row-wise), and connecting Covid-19 incidence/density (right cluster, column-wise). Right panel: With no resolved data for UV per province, we used elevation of capital city as a UV estimate (i.e. altitude - selected from a number of other metrics). Annotation blocks (from left panel, see above) are shown per province; those consistent with UV-vs-incidence have a grey border (19), those inconsistent with UV-vs-incidence have a cyan border (6). The pattern provides, perhaps for the first time, some evidence of correlation between UV and Covid-19 incidence across altitudes and not latitudes - with UV being a strong candidate for an additional driver of seasonality at lower altitudes elsewhere (summer months).

Artificial means to irradiate public spaces might be an option.

\section{Data availability}

Source data

Covid-19 data from ECDC available from: : https://www.ecdc. europa.eu/en/publications-data/download-todays-data-geographic-distribution-covid-19-cases-worldwide 5-May-2020).
Covid-19 data from Peru available from: https://covid19.minsa.gob. pe/sala_situacional.asp (downloaded 12-May-2020).

\section{Acknowledgements}

A previous version of this article was published on OSF Preprints: https://doi.org/10.31219/osf.io/397yg (Karapiperis et al., 2020).

Stelios Papastratos is an external member of BCPL.
Anderson RM, Heesterbeek $\mathrm{H}$, Klinkenberg D, et al.: How will country-based mitigation measures influence the course of the COVID-19 epidemic? Lancet. 2020; 395(10228): 931-34.

PubMed Abstract | Publisher Full Text | Free Full Text

Araújo MB, Naimi B: Spread of SARS-CoV-2 Coronavirus likely to be constrained by climate. medRxiv. 2020.

Publisher Full Text

Asyary A, Veruswati M: Sunlight exposure increased Covid-19 recovery rates: A study in the central pandemic area of Indonesia. Sci Total Environ. 2020; 729: 139016. PubMed Abstract | Publisher Full Text | Free Full Text 
Auler AC, Cássaro FAM, da Silva VO, et al.: Evidence that high temperatures and intermediate relative humidity might favor the spread of COVID-19 in tropical climate: A case study for the most affected Brazilian cities. Sci Total Environ. 2020; 729: 139090

PubMed Abstract | Publisher Full Text | Free Full Text

Bannister-Tyrrell M, Meyer A, Faverjon C, et al:: Preliminary evidence that higher temperatures are associated with lower incidence of COVID-19, for cases

reported globally up to 29th February 2020. medRxiv. 2020.

Publisher Full Text

Briz-Redón Á, Serrano-Aroca Á: A spatio-temporal analysis for exploring the effect of temperature on COVID-19 early evolution in Spain. Sci Total Environ. 2020; 728: 138811.

PubMed Abstract | Publisher Full Text | Free Full Text

Bukhari Q, Jameel Y: Will Coronavirus Pandemic Diminish by Summer? SSRN. 2020.

Publisher Full Text

Calbó J, Pages D, González JA: Empirical studies of cloud effects on UV radiation: A review. Rev Geophys. 2005; 43.

Publisher Full Text

Carleton T, Meng KC: Causal empirical estimates suggest COVID-19

transmission rates are highly seasonal. medRxiv. 2020.

Publisher Full Text

Carleton T, et al.: Ultraviolet radiation decreases CovID-19 growth rates: Global causal estimates and seasonal implications. SSRN. 2020.

Publisher Full Text

Carleton T, Cornetet J, Peter Huybers P, et al:: Roles of meteorological conditions in COVID-19 transmission on a worldwide scale. medRxiv. 2020.

Publisher Full Text

Chiyomaru K, Takemoto K: Global COVID-19 transmission rate is influenced by precipitation seasonality and the speed of climate temperature warming medRxiv. 2020

Publisher Full Text

Darnell ME, Subbarao K, Feinstone SM, et al:: Inactivation of the coronavirus that induces severe acute respiratory syndrome, SARS-CoV. J Virol Methods. 2004; 121(1): 85-91.

PubMed Abstract | Publisher Full Text | Free Full Text

Engelsen O: The relationship between ultraviolet radiation exposure and vitamin D status. Nutrients. 2010; 2(5): 482-95.

PubMed Abstract | Publisher Full Text | Free Full Text

Holmes KV: SARS-associated coronavirus. N Engl J Med. 2003; 348(20): 1948-51. PubMed Abstract | Publisher Full Text

Hunter P: The spread of the COVID-19 coronavirus: Health agencies worldwide prepare for the seemingly inevitability of the COVID-19 coronavirus becoming endemic. EMBO Rep. 2020; 21(4): e50334.

PubMed Abstract | Publisher Full Text | Free Full Text

lanevski A, Zusinaite E, Shtaida N, et al.: Low Temperature and Low UV Indexes Correlated with Peaks of Influenza Virus Activity in Northern Europe during 2010-2018. Viruses. 2019; 11(3): 207.

PubMed Abstract | Publisher Full Text | Free Full Text

Juzeniene A, Li-Wei Ma L-W, Kwitniewski M, et al.: The seasonality of pandemic and non-pandemic influenzas: the roles of solar radiation and vitamin $\mathrm{D}$. Int $J$ Infect Dis. 2010; 14(12): e1099-105.

PubMed Abstract | Publisher Full Text

Karapiperis C, Kouklis P, Papastratos S, et al:: Assessment for the seasonality of Covid-19 should focus on ultraviolet radiation and not "warmer days". OSF Preprints. 2020

http://www.doi.org/10.31219/osf.io/397yg

Kim KH, Tandi TE, Choi JW, et al.: Middle East respiratory syndrome coronavirus (MERS-CoV) outbreak in South Korea, 2015: epidemiology, characteristics and public health implications. J Hosp Infect. 2017; 95(2) 207-13.

PubMed Abstract | Publisher Full Text | Free Full Text

Kissler SM, Tedijanto C, Goldstein E, et al:: Projecting the transmission dynamics of SARS-CoV-2 through the postpandemic period. Science. 2020; 368(6493): 860-868.

PubMed Abstract | Publisher Full Text | Free Full Text

Lebarbenchon C, Jaeger A, Bastien M, et al:: Absence of Coronaviruses, Paramyxoviruses, and Influenza A Viruses in Seabirds in the Southwestern Indian Ocean. J Wildl Dis. 2013; 49(4): 1056-59.

PubMed Abstract | Publisher Full Text

$\mathrm{Li} \mathrm{H}$, Xiao H, Zhu R, et al.: Warmer weather and global trends in the coronavirus COVID-19. medRxiv. 2020

Publisher Full Text

Li Q, Macdonald S, Bienek C, et al.: Design of a UV-C irradiation process for the inactivation of viruses in protein solutions. Biologicals. 2005; 33(2): 101-10. PubMed Abstract | Publisher Full Text

Liu J, Zhou J, Yao J, et al.: Impact of meteorological factors on the COVID-19 transmission: A multi-city study in China. Sci Total Environ. 2020; 726: 138513. PubMed Abstract | Publisher Full Text | Free Full Text

Luo W, Magumder MS, Liu D, et al:: The role of absolute humidity on transmission rates of the COVID-19 outbreak. medRxiv. 2020.

Publisher Full Text

Lytle CD, Sagripanti JL: Predicted inactivation of viruses of relevance to biodefense by solar radiation. J Virol. 2005; 79(22): 14244-52.

PubMed Abstract | Publisher Full Text | Free Full Text
Ma Y, Ma Y, Liu J, et al.: Effects of temperature variation and humidity on the mortality of COVID-19 in Wuhan. medRxiv. 2020.

Publisher Full Text

Martinez ME: The calendar of epidemics: Seasonal cycles of infectious

diseases. PLoS Pathog. 2018; 14(11): e1007327.

PubMled Abstract | Publisher Full Text | Free Full Text

Mecenas P, Renata Bastos R, Vallinoto A, et al.: Effects of temperature and humidity on the spread of COVID-19: A systematic review. medRxiv. 2020 Publisher Full Text

Merow C, Urban MC: Seasonality and uncertainty in COVID-19 growth rates. medRxiv. 2020.

Publisher Full Text

Metsalu T, Vilo J: ClustVis: a web tool for visualizing clustering of multivariate data using Principal Component Analysis and heatmap. Nucleic Acids Res. 2015; 43(W1): W566-70.

PubMed Abstract | Publisher Full Text | Free Full Text

Neher RA, Dyrdak R, Druelle V, et al:: Potential impact of seasonal forcing on a SARS-CoV-2 pandemic. Swiss Med Wkly. 2020; 150: w20224.

PubMed Abstract | Publisher Full Text

Nickbakhsh S, Ho A, Marques DFP, et al.: Epidemiology of seasonal coronaviruses: Establishing the context for the emergence of coronavirus disease 2019. J Inf Dis. 2020; 222(1): 17-25.

PubMed Abstract | Publisher Full Text | Free Full Text

Oliveiros B, Caramelo L, Ferreira NC, et al:: Role of temperature and humidity in the modulation of the doubling time of COVID-19 cases. medRxiv. 2020. Publisher Full Text

Pedrosa RHL: The dynamics of Covid-19: weather, demographics and infection timeline. medRxiv. 2020

Publisher Full Text

Rae C, Koudelka KJ, Destito G, et al:: Chemical addressability of ultravioletinactivated viral nanoparticles (VNPs). PLoS One. 2008; 3(10): e3315.

PubMed Abstract | Publisher Full Text | Free Full Text

Şahin M: Impact of weather on COVID-19 pandemic in Turkey. Sci Total Environ 2020; 728: 138810.

PubMed Abstract | Publisher Full Text | Free Full Text

Sajadi MM, Habibzadeh P, Vintzileos A, et al.: Temperature, Humidity and Latitude Analysis to Predict Potential Spread and Seasonality for COVID-19. SSRN. 2020.

Publisher Full Text

Shi $\mathrm{P}$, Dong $\mathrm{Y}, \mathrm{Yan} \mathrm{H}$, et al.: Impact of temperature on the dynamics of the COVID-19 outbreak in China. Sci Total Environ. 2020; 728: 138890.

PubMed Abstract | Publisher Full Text | Free Full Text

Sobral MFF, Duarte GB, da Penha Sobral AIG, et al:: Association between climate variables and global transmission of SARS-CoV-2. Sci Total Environ. 2020; 729: 138997.

PubMed Abstract | Publisher Full Text | Free Full Text

Suarez Salas LF, Flores Rojas JL, Pereira Filho AJ, et al:: Ultraviolet solar radiation in the tropical central Andes (12.0 degrees S). Photochem Photobiol Sci. 2017; 16(6): 954-71.

PubMed Abstract | Publisher Full Tex

Tamerius J, Nelson MI, Zhou SZ, et al.: Global influenza seasonality: reconciling patterns across temperate and tropical regions. Environ Health Perspect. 2011; 119(4): 439-45

PubMed Abstract | Publisher Full Text | Free Full Text

Tseng CC, Li CS: Inactivation of viruses on surfaces by ultraviolet germicidal irradiation. J Occup Environ Hyg. 2007; 4(6): 400-5.

PubMed Abstract | Publisher Full Text | Free Full Text

Ujiie M, Tsuzuki S, Ohmagari N: Effect of temperature on the infectivity of COVID-19. Int J Infect Dis. 2020; 95: 301-03.

PubMed Abstract | Publisher Full Text | Free Full Text

van Doremalen N, Bushmaker T, Morris DH, et al.: Aerosol and Surface Stability of SARS-CoV-2 as Compared with SARS-CoV-1. N Engl J Med. 2020; 382(16): 1564-1567.

PubMed Abstract | Publisher Full Text | Free Full Text

Vetter P, Eckerle I, Kaiser L: Covid-19: a puzzle with many missing pieces. BMJ. 2020; 368: m627.

PubMed Abstract | Publisher Full Text

Welch D, Buonanno M, Grilj V, et al.: Far-UVC light: A new tool to control the spread of airborne-mediated microbial diseases. Sci Rep. 2018; 8(1): 2752. PubMed Abstract | Publisher Full Text | Free Full Text

Wu Y, Jing W, Liu J, et al.: Effects of temperature and humidity on the daily new cases and new deaths of COVID-19 in 166 countries. Sci Total Environ. 2020; 729: 139051.

PubMed Abstract | Publisher Full Text | Free Full Text

Xu B, Kraemer MUG: Open access epidemiological data from the COVID-19 outbreak. Lancet Infect Dis. 2020; 20(5): 534.

PubMed Abstract | Publisher Full Text | Free Full Text

Yao Y, Pan J, Liu Z, et al:: No association of COVID-19 transmission with temperature or UV radiation in Chinese cities. Eur Respir J. 2020; 55(5): 2000517.

PubMed Abstract | Publisher Full Text | Free Full Text

Zumla A, Hui DS, Perlman S: Middle East respiratory syndrome. Lancet. 2015; 386(9997): 995-1007.

PubMed Abstract | Publisher Full Text | Free Full Text 


\section{Open Peer Review}

\section{Current Peer Review Status: ? $\mathrm{X}$}

\section{Version 1}

Reviewer Report 10 May 2021

https://doi.org/10.5256/f1000research.27330.r82697

(c) 2021 Baylis M. This is an open access peer review report distributed under the terms of the Creative Commons Attribution License, which permits unrestricted use, distribution, and reproduction in any medium, provided the original work is properly cited.

\section{Matthew Baylis}

Institute of Infection, Veterinary and Ecological Sciences, University of Liverpool, Liverpool, UK

This paper explores the possible impact of UV exposure on Covid-19. In my view it has a number of weaknesses.

1. The first paragraph is strange. It presents some arguably minor aspects of Covid-19 and then concludes we need to understand climate factors. This is a non-sequiteur. The paragraph should present a coherent argument for why we need to understand climate impacts on Covid-19.

2. The second paragraph considers some relevant literature. This is helpful, but not up to date [to today] - notably missing ${ }^{1}$ (interest declared).

3. The reference to deploying artificial UV-C is strange and seems wrong in a paper about seasonality. As described, UV-C from artificial sources could be used to inactivate SARS-CoV2 in e.g., hospitals, but it cannot influence seasonality of transmission. I suggest this is because it is in a paragraph taken from the pre-print.

4. Page 4. The paragraph on seabirds is very weak and should be removed. The cited paper found no evidence of coronavirus [or other viruses] in any season in the seabirds; the lack of detection of coronaviruses is not evidence at all of an impact of season.

5. Page 4. The discussion of SARS/MERS should consider the evidence that they had a seasonal cycle or were affected by climate or UV.

6. Page 4. The suggestion that the southern hemisphere seems to have escaped the worst (supportive of seasonality etc) has been overtaken by events (e.g., Brasil) and the authors may wish to update the statement. Really, this was the danger from publishing analyses so early in the pandemic. This, and other examples, seem to be cherry picking examples to support their hypothesis.

7. Figure 1. I have several concerns about this figure. The authors say the figure will be 
updated but it ends in May 2020. It is very hard to discern patterns in the figure It says in the title "three countries" but I think there are $>140$. The data are counts - of what? Cases, hospitalisations, deaths? Whichever, it is well known that different countries count these measures in different ways [e.g., UK, death from covid = death by any cause $<28$ days from a covid+ve test]. Further, many other factors will affect these counts and it is wrong to only look at climate factors.

8. Figure 2 is very hard to follow. Nevertheless, I note that the right-hand panel makes no attempt to include population density; while in the left hand panel it is mentioned but not actually accounted for. In both cases, population density is strongly associated with altitude, and altitude with UV - so population density MUST be accounted for.

All in all, this is a weak paper. Its arguments are poor, it cherry picks examples, the data analysis is rudimentary and needs to include many other possible explanatory factors in addition to those related to UV.

\section{References}

1. Metelmann S, Pattni K, Brierley L, Cavalerie L, et al.: Impact of climatic, demographic and disease control factors on the transmission dynamics of COVID-19 in large cities worldwide.One Health. 2021; 12: 100221 PubMed Abstract | Publisher Full Text

Is the topic of the opinion article discussed accurately in the context of the current literature?

Partly

Are all factual statements correct and adequately supported by citations? Partly

Are arguments sufficiently supported by evidence from the published literature? No

Are the conclusions drawn balanced and justified on the basis of the presented arguments? No

Competing Interests: No competing interests were disclosed.

Reviewer Expertise: Epidemiology; climate and health; One Health.

I confirm that I have read this submission and believe that I have an appropriate level of expertise to state that I do not consider it to be of an acceptable scientific standard, for reasons outlined above.

Reviewer Report 18 August 2020

https://doi.org/10.5256/f1000research.27330.r68930 
(c) 2020 Zubieta-Calleja G. This is an open access peer review report distributed under the terms of the Creative Commons Attribution License, which permits unrestricted use, distribution, and reproduction in any medium, provided the original work is properly cited.

\section{Gustavo Zubieta-Calleja}

High Altitude Pulmonary and Pathology Institute IPPA, La Paz, Bolivia

The article "Preliminary evidence for seasonality of Covid-19 due to ultraviolet radiation" is of great interest in this COVID-19 Pandemic. The article is well written however a few points need to be addressed:

1. The first Figure is confusing and difficult to understand. The countries mentioned cannot be totally understood in the $Y$ axis. The $X$-axis cannot be discerned, but it is assumed it is dates. The overall idea is good as it shows the seasonal variation.

2. The U-V radiation and high altitude has been discussed before in South America. The first mention as to the U-V radiation was in an article on it's effect on the eyes of high altitude residents:

Acta Ophthalmol. doi: 10.1111/j.1755-3768.2008.01488.x. Epub 2009 Mar 20. Lens autofluorescence is not increased at high altitude ${ }^{1}$.

The concept of the benefits of high altitude and the Ultra-Violet sterilizing effects were mentioned in an article on Longevity at high altitude in 2017

https://zuniv.net/pub/Longevity.pdf2.

At the beginning of the COVID-19 pandemia, several interviews, website publications and articles on the subject were published. Full references are available at:

https://altitudeclinic.com/blog/2020/06/covid-19-pubs/3.

Some should be included in the Timeline Box 1.

\section{References}

1. Kessel L, Kofoed PK, Zubieta-Calleja G, Larsen M: Lens autofluorescence is not increased at high altitude.Acta Ophthalmol. 2010; 88 (2): 235-40 PubMed Abstract | Publisher Full Text

2. Zubieta-Calleja G, Zubieta-DeUrioste N: Extended longevity at high altitude: Benefits of exposure to chronic hypoxia. BLDE University Journal of Health Sciences. 2017; 2 (2). Publisher Full Text

3. High Altitude Pulmonary and Pathology Institute in La Paz, Bolivia 3500. High Altitude Pulmonary.

4. Arias-Reyes C, Zubieta-DeUrioste N, Poma-Machicao L, Aliaga-Raduan F, et al.: Does the pathogenesis of SARS-CoV-2 virus decrease at high-altitude?. Respir Physiol Neurobiol. 277: 103443

PubMed Abstract | Publisher Full Text

Is the topic of the opinion article discussed accurately in the context of the current literature?

Partly

Are all factual statements correct and adequately supported by citations? 
Yes

Are arguments sufficiently supported by evidence from the published literature? Yes

Are the conclusions drawn balanced and justified on the basis of the presented arguments? Yes

Competing Interests: No competing interests were disclosed.

Reviewer Expertise: High altitude medicine, physiology, chronic hypoxia, chronic mountain sickness, U-V studies at high altitude, biophysics, COVID clinical aspects, silent hypoxemia, pneumolysis

I confirm that I have read this submission and believe that I have an appropriate level of expertise to confirm that it is of an acceptable scientific standard, however I have significant reservations, as outlined above.

\section{Comments on this article}

\section{Version 1}

Author Response ( F1000Research Advisory Board Member ) 21 Dec 2020

Christos Ouzounis, Centre for Research and Technology Hellas, Thermi, Greece

data available at: https://osf.io/kgxuf/

Competing Interests: No competing interests were disclosed.

Author Response ( F1000Research Advisory Board Member ) 30 Jun 2020

Christos Ouzounis, Centre for Research and Technology Hellas, Thermi, Greece

We will try to keep Box 1 up-to-date, until the end of the review process on F1000Research.

30-Mar: Guasp et al., 2020

02-Apr: Bäcker, 2020

09-Apr: Alipio, 2020

19-Apr: Buonanno et al., 2020

04-May: Schuit et al., 2020

18-May: Bäcker, 2020

29-May: Rhodes et al., 2020

Papers-preprints that are not dated cannot be listed. We list the date of submission if available. 
Competing Interests: No competing interests.

The benefits of publishing with F1000Research:

- Your article is published within days, with no editorial bias

- You can publish traditional articles, null/negative results, case reports, data notes and more

- The peer review process is transparent and collaborative

- Your article is indexed in PubMed after passing peer review

- Dedicated customer support at every stage

For pre-submission enquiries, contact research@f1000.com 